\title{
A new species of Leptolalax (Anura: Megophryidae) from Mizoram, North-eastern India
}

\author{
SAIBAL SENGUPTA ${ }^{1}$, SAIPARI SAILO ${ }^{2}$, H.T. LALREMSANGA ${ }^{3}$, ABHIJIT DAS $^{4} \&$ INDRANEIL DAS $^{5,6}$ \\ ${ }^{1}$ Department of Zoology, Arya Vidyapeeth College, Guwahati 781 016, Assam, India \\ ${ }^{2}$ Developmental Biology Laboratory, Department of Zoology, North Eastern Hill University, Mawlai, Mawkynroh, Shillong 793 022, \\ Meghalaya, India \\ ${ }^{3}$ Department of Zoology, Mizoram University, Aizawl 796 012, Mizoram, India \\ ${ }^{4}$ Division of Herpetology, Aaranyak, 50 Samanwoy Paths, Survey, Beltola, Guwahati 781 028, Assam, India \\ ${ }^{5}$ Institute of Biodiversity and Environmental Conservation, Universiti Malaysia Sarawak, 94300, Kota Samarahan, Sarawak, \\ Malaysia \\ ${ }^{6}$ Corresponding author. E-mail: idas@ibec.unimas.my
}

\begin{abstract}
A new species of megophryid frog of the genus Leptolalax is described from the Tamdil wetlands of Mizoram State, north-eastern India. L. tamdil new species, is compared with congeners from India and other parts of south-east Asia. The new species is diagnosable in showing the following combination of characters: SVL $32.3 \mathrm{~mm}$ in the only male and 31.8 $\mathrm{mm}$ in the only female known; dorsum tuberculate; eyelids with tubercles; tympanum and supratympanic fold distinct; supratympanic fold extending to posterior edge of tympanum; macroglands, including preaxillary, pectoral, femoral and ventrolateral glands present; Finger II > I; toe tips not dilated, bearing dermal fringes; relatively long hind limbs, with heels in contact when limbs are held perpendicular to body; dorsum with dark blotches; flanks with small dark blotches; dark tympanic mask present; venter pale; labial bars present and limbs with dark cross-bars.
\end{abstract}

Key words: Leptolalax tamdil sp. nov. Megophryidae, Mizoram, north-eastern India

\section{Introduction}

With the addition of two species to north-east India's faunal list (Humtsoe et al. 2008; Das et al. 2010), the genus Leptolalax Dubois 1980 (Anura: Megophryidae) contains 24 species (Frost 2009; Matsui et al. 2009; Rowley and Trung 2009). Members are distributed in subtropical and tropical south-east Asia and east Asia, with a range from southern China and north-eastern India, Myanmar, Thailand, Cambodia, Vietnam and Peninsular Malaysia, in addition to Borneo (Inger et al. 1999; Iskandar and Colijn 2000; Humtsoe et al. 2008; Frost 2009).

During herpetological collections for an inventory at Tamdil, a wetland of national importance in Mizoram state, north-eastern India (Fig. 1), we collected two specimens of a hitherto undescribed species of Leptolalax, which is described in this paper.

\section{Material and methods}

The two adult frogs constituting the type series of the new species were collected from under rocks along a stream at night. They were photographed prior to euthanasia, fixed in formalin and subsequently transferred to $70 \%$ ethanol. Sex was determined through dissection. The following measurements were taken with Mitutoyo $^{\text {TM }}$ dial vernier callipers (to the nearest $0.1 \mathrm{~mm}$ ), 27 mo after collection: SVL, snout-vent length (from tip of snout to vent); IN, internarial distance (distance between nostrils); HL, head length (distance 